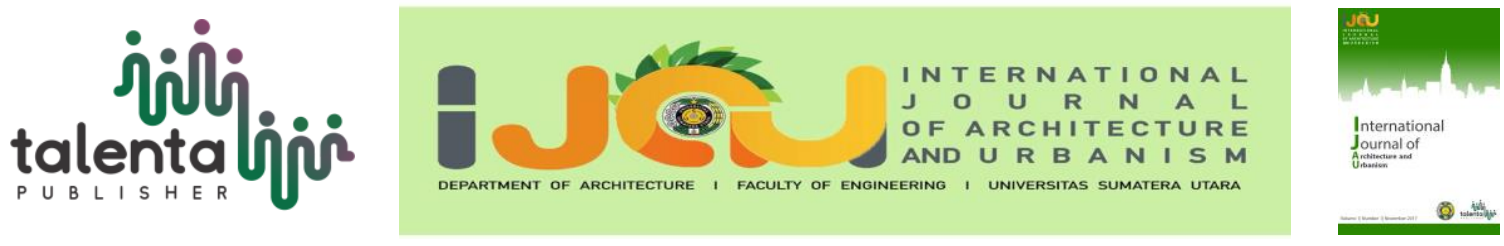

\title{
Design of North Sumatera Paradise Gallery in Medan City (Metaphor Architecture)
}

\author{
Andalucia $^{1 *}$, Robby Honoris ${ }^{1}$ \\ ${ }^{l}$ Department of Architecture, Universitas Sumatera Utara, Medan, Indonesia
}

\begin{abstract}
The purpose of this Art Gallery designing is for giving space for the local artist to place and promote their art products. It's because Medan city has not decent gallery according to the national standard. The surplus of this art gallery out of showing fine art is giving room experience impression to support fine art showcase. The theme of the building is a metaphor of water ripple to represent Babura river, so the art installation to the building is using water concept that gives unique aspect to building and can be art identity of Medan city. This gallery building is hoped to fulfill gallery estimation which is decent in national and international rank because Medan is the third biggest town in Indonesia where been visited by so many foreign tourists.
\end{abstract}

Keyword: gallery, art, metaphor, water

\section{Introduction}

North Sumatera is one of the provinces in Indonesia that has a stout culture. Many cultures are left behind as developments in modern times. The culture and heritage that exist in North Sumatra is getting forgotten and slowly becoming lost, so the need for cultural education through a container like a building. According to Effendy Naibaho, the development of the art in North Sumatra is considered still inferior to the cities in Java. Therefore, the need for additional facilities and art building that can support the production of artists in North Sumatra is necessary.

In Quotation Tribun Medan 13 June 2016, Togu Sinambela, founder of Galeri Payung Teduh said that the lack of space or container to accommodate the work of field and surrounding artists. Togu considered that the lack of buyers of artwork in Medan not symbolizing the lack of appreciation. Minimal gratitude resulted in Togu's productivity declining as art enthusiasts were reduced. It will be concluded that the value of artwork in North Sumatra will decrease according to its review.

*Corresponding author at:Department of Architecture, Faculty of Engineering, Universitas Sumatera Utara, Jalan Perpustakaan Gedung J07, Medan 20155, Indonesia

E-mail address: andaluciazurdani@gmail.com 
Currently, there are ten art organizations in the field of art that listed in Medan, such as SIMPASSRI, Sanggar Sekar Gunung, Kelompok Gorga, Zumm Galeri, Seni Experimental Medan, Galeri Tong Sampah, Me \& Art, Kelompok Medan, ASRI 45, Ungkapan Cita Rasa (UTARA), dan Habitat Seni Laklak. However, these activities are not supported by adequate places, resulting in many activities being carried out separately and in less representative places for art activities. As a result, most of the activities undertaken received less attention from the community. Here are the tables that contain several galleries located in the city of Medan.

The Gallery is not one of the main destinations for visitors, immigrants or the general public in seeking entertainment and relaxation. The existence of the Gallery can be said to be a lack of enthusiasts compared to places like cinema, mall, café, and others. Whereas if designed well, the gallery can be one of tourism potential that can increase the number of visitors. Based on the above-mentioned came a thought to draft a container of cultural exhibition and local production goods in the area of Medan which has the potential of education with the concept of tourism, the goal is to re-generate the productivity of local works of North Sumatra people, North of Sumatra Gallery, and introduce to domestic tourists as well overseas about the arts and the great potential of North Sumatera. Meanwhile, Medan is an embrace city regarding fine arts. The position of Medan in the treasury of national and international art is still very wide open, because of the geographical location of Medan is very close to Malaysia and Singapore which has long been touted as one of the countries in Southeast Asia which has a strong art pulse. It is a great opportunity for local artists, as well as motivation to continue to work to be able to show its echoes in the ranks of national and international art standard.

North Sumatra culture is also famous with its diverse ethnic tribes. Based on the results of the 2010 population census from BPS data (Central Bureau of Statistics), the percentage of ethnic groups in North Sumatra are Batak (Karo, Simalungun, Tapanuli / Toba, Mandailing and Pakpak) 44.75 percent, Javanese (Betawi, Banten, Java and Madura) 33.40 percent, Nias 6.36 percent, China 2.71 percent, Minang 2.66 percent and Aceh 0.97 percent. From this diversity, many diverse artists are created. This gallery is expected to show the artistic side of the tribe's diversity to show the true identity of North Sumatra. This art showcase is assumed to be storage, exhibition and sales collection and production culture of North Sumatra, as well as an interesting place as a tourist attraction. Thus, the gallery can be a place of promotion or representatives to introduce the Culture contained in North Sumatra. With the showcase, is expected to reinforce the image of North Sumatra as a wealthy island culture of each tribe, to attract tourists to come to North Sumatera. 


\section{Literature Review}

\subsection{Location Selection's Criteria}

Site selection is based on several criteria, such as: first, based on RUTRK (Urban Landuse Plan) in Medan City. Site location must be by land use plan. Second, environmental sites are in a strategic spot, the environment with a nice image and cultured according to its function with the surrounding environment that can support the building function to be built. Third, accessibility of the site is easy to achieve, and the presence of means of transportation is passing through the site.

The criteria for choosing the locus for the design of the Paradise of NorthSumatera Gallery building in Medan city effectively, are as follows:First, site location is an easy-to-reach area for tourists and local people. Second, site location is an empty land that has met the criteria in the design of this building.Third, efficient site circulation for users. Fourth, the site is not a government-prohibited site for development.Regarding effort, the site should be located in areas easily accessible by both local and non-local tourists. Both of them with private vehicles, as well as public transport.The area around the site is close to a building or infrastructure that requires services related to commercial facilities and others.

\subsection{Users and Activities in Gallery}

Gallery has the core function as a container/communication tool between consumers and producers. Manufacturers in question are the artists while consumers are collectors and the public. The gallery function according to Trade Kakanwil includes:first, as a place of promotion of art goods.Second, as a place to develop the market for the artists.Third, as a place to preserve and introduce works of art and culture from all over Indonesia.Fourth, as a place of business coaching and business organization between artists and managers.Fifth, as a bridge in the framework of the existence of entrepreneurship development.Sixth, as one of the objects of national tourism development [1].

The types of galleries can be distinguished as follows: First, gallery inside Museum is an exclusive gallery to show off objects that are considered to have historical value or scarcity. Second, Contemporary Gallery is a gallery that has commercial functions and is owned by individuals. Third, Vanity Gallery, artistic art galleries that can be transformed into an activity in it, such as education and employment. Forth, Gallery of Architecture to showcase the results of works in the field of architecture that has the difference between 4 types of galleries according to each character. Fifth, Commercial Gallery is gallery for profit, business personally to sell works. Not oriented to seek collective benefit from national or local government[2].

The space constraint of a gallery include:Exhibition Room / Place to showcase the artwork, Workshop / Place to make or repair the artwork, Stock Room / Place to accommodate or put the 
artwork, Restoration Room / Place to maintain the artwork, Auction Room / Place to promote the artwork and as a place of sale and purchase of the artwork, Multifunction Hall ,Service Room I Place consisting of room ME, AHU, Cleaning Service \& OB, Security, Café / Place to support gallery facilities to enjoy drinks and snacks[4].

\section{Design Method}

Design methods are usually started from some approaches related to design objectives. These approaches are: first, impend with field study. It is an approach to collecting existing data by making data acquisition from a related institution, field observation, and the surrounding environment, activity or activity, existing function and analyzing potential and occurring problems in surrounding environment and obtain picture and data from field study survey. Second, approach by literature study. It is an approach to collecting data to analysis the problems found and solving problems based on references deemed relevant and supportive in the design process such as journals, manuals, building standards and safety standards in buildings by the project function and feasibility. Third, approach by comparative study. It is an approach to conducting comparative studies on buildings that have similar utility and themes as well as an approach to finding existing data. Resources can be either direct survey or written sources such as books, print media, the Internet and other sources deemed to support the design process.

Data collection method are usually started from some approaches with collecting data. These approaches are: First, observation. That is data collection by way of field survey. Observe the existing issues on the site and record the spot data, the potential of the place and take the required images.Second, literature Method. In obtaining the necessary data and information, used literature study and field study. Library study was acquired by reviewing the literature and some direct observation results to the field to earn data related to the carrying capacity of roads and functions that have been around the area of Batang Kuis. Third, primary data. Primary data in the form of data related to the physical data of the region. Primary data is qualitative and quantitative data generated through interviews and direct observation. The primary data areland condition, the condition of shape and building mass, circulatory condition, open space condition, pedestrian condition, the condition of the marker, the condition of supporting activities, preservation conditions.Forth, secondary data. Secondary data in the form of maps, policies in the development area as well as assumptions and analysis. These secondary data are qualitative and quantitative data obtained from the literature review obtained from related sources, such as: First, data about the condition of a location of design, achievement of a location obtained from google earth and google maps. Last, data on land use, this data can be obtained from Landuse plan in Medan City(RUTRK).Last, literature study. Article study is a technique of data collection conducted by researchers by reviewing the theories, opinions and 
the main ideas in print media, especially the books that support and relevant in the problems discussed in the study [3].

\section{Results and Discussion}

\subsection{Theme and Building Concept}

The relation with the idea of tangible metaphor applied to the building formation, the mass formation and composition must reflect the characteristics of the surrounding environmental perceptions. Drawn from the general description of an art gallery, the key word here is the Babura river which consists of water elements that use a visual depiction of water in a small object drop will cause water ripples (Figure 1).

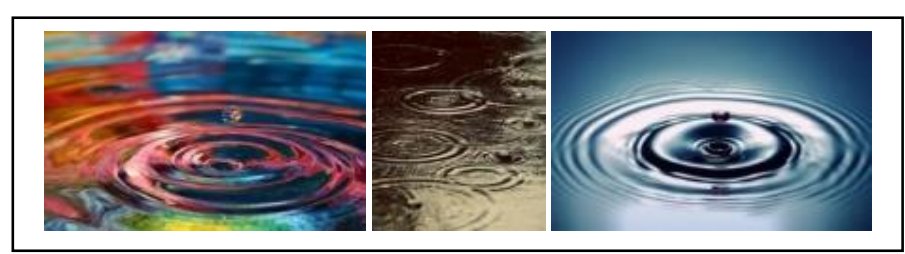

Figure 1. Water Ripples' Illustration

(Source: http://www.splendidhabitat.com/one-small-act-gift-giving-can-create-ripple-effectacoss-world)

\subsection{Circulation of Building Concept}

The Visitors start from the site entrance and park in the basement or direct the entry way to the gallery and register through the lobby and enter the splash water zone as the welcome region. After that, the search start in the building begins when the gallery is an ongoing temporary exhibition or not from the left chamber of the building or directly from the center of the seating start a curved search to give the impression of water ripple and the sway of elegant space (Figure 2).

After climbing on the second floor, travel on this zone themed giant territory or devoted to large sculptures and ceramics are rather difficult to move to the next level. In this section, there are many voids from the second floor to the first floor to maximize the appearance of the display. At the back of the 2nd-floor plan, there is an optional trek to proceed to the third floor or choose to explore the 2nd-floor outdoor section. Then continues to the rooftop garden path connected by the bridge to the outdoor café and can continue using the ramp down to the outdoor exhibition yard and the water's edge of the site.

If the visitor chooses to extend the sessions up to the third floor, then visitors can experience the artificial underwater experience of the building. On the third floor is using a kind of skylight glass roof as the base of the pool filled with water at the top, so it will display the underwater visual impression due to refraction of light into the water and produce an underwater impact (Figure 2). The other features in the gallery building are workshops, photo studios, cafes, halls, amphitheater, and outdoor exhibitions. 


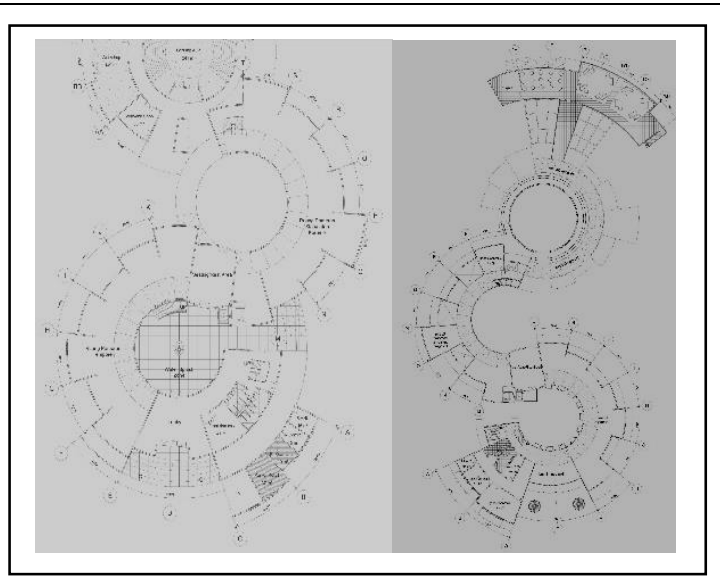

Figure 2. Building's Blueprint

\subsection{The Concept of Outer Space}

Outer space can serve as a circulation vehicle, pedestrian, park, seating area, outdoor café, amphitheater and so on. Site formation follows the shape of water ripples in segments. Outer space also retains the concept of playing with water starting from the front yard; there is a watered-in plane that lines the waterway. Up to the side of the building using the concept of water running down the wall and form a pool of water plus a fountain. Until the back of the site, there is an outdoor exhibition area and amphitheater blend with the river (Figure 3).

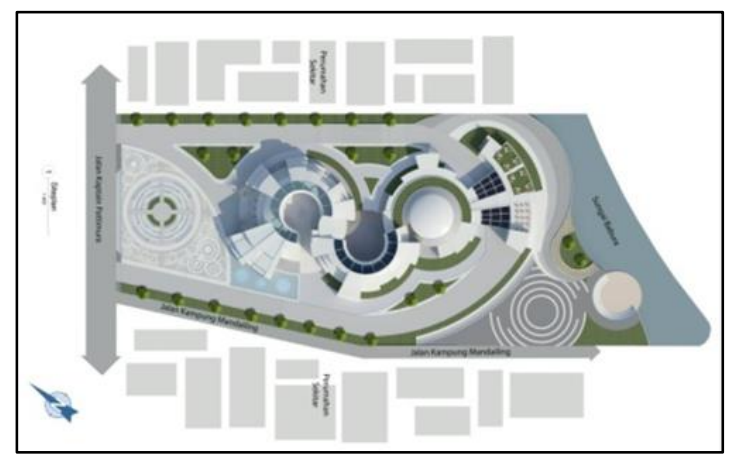

Figure 3. Building's Landscape

\subsection{Concept of Pedestrian}

At the front of the project site, there is a pedestrian track and is still feasible with a width of \pm 2 $\mathrm{m}$ and a ditch width of $\pm 1.5 \mathrm{~m}$. It is planned that the ditch will be closed so that the pedestrian path will be about $\pm 3 \mathrm{~m}$ wide. Closing the ditch does not mean the water from the project site can not flow properly, of course, there will be a separate settlement (Figure 4).

In the previous discussion green, open space can be used as a park and pedestrian paths around the park. The pedestrian line is also used to show the character of the building that serves as an art building. Throughout Kampung Mandailing street adjacent to the project location is planned to be made a pedestrian path so that it can be accessed up to the back. At the same time, intended visitors and employees will perform prayers at the mosque adjacent to the location so that access is required (Figure 4). 


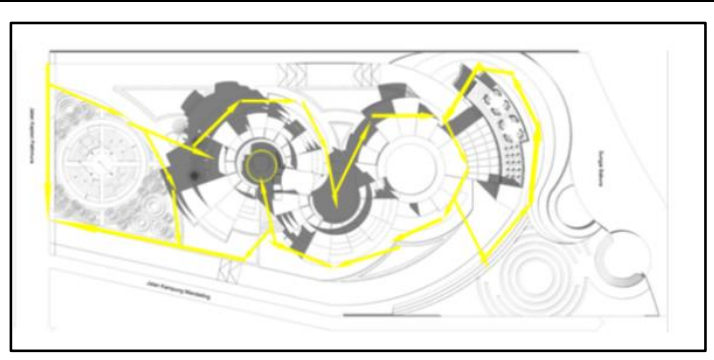

Figure 4. Pedestrian Circulation

\subsection{Vehicle Concept}

The circulation is divided into two, the circulation just for drop off and the movement of vehicles parked in the basement. As in the picture below, a large path that made of asphalt is the area of the vehicle circulation. The path other than the picture above, namely the basement can be seen from the basement floor plan below. Free roaming circulation surrounds the building with a 4 meters wide pedestrian distinct road width. The freely designed grooves can surround an entire section of buildings and outdoor facilities (Figure5).

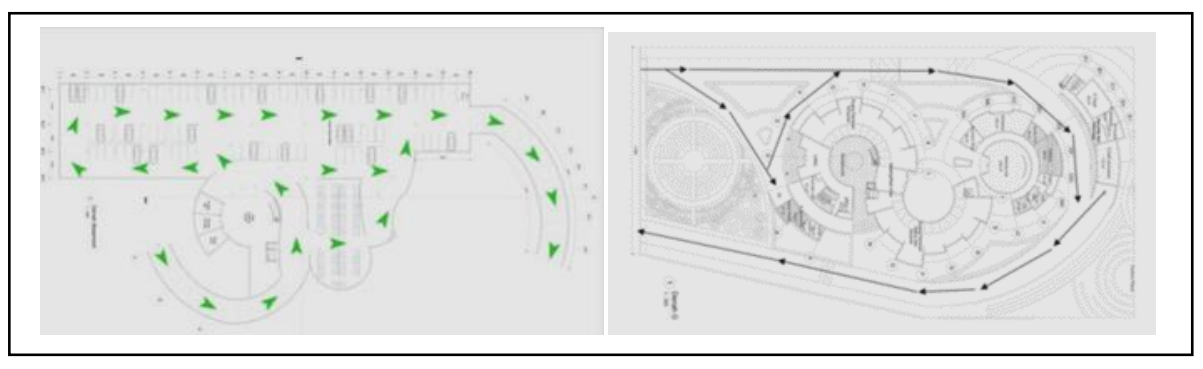

Figure 5. Vehicles Circulation

\subsection{Building Mass Concept}

The building mass arrangement derived from abstract based on intangible metaphorical concepts. The Figure composition follows large and irregular water ripple segments. By the essential theme that connects to art and abstract, the building deliberately cuts back and forth. At the front of the building designed water running down the walls gives the powerful concept of water in buildings that themed water ripple metaphor. The white color is chosen for the building is to represent the characteristic of water that is clear and plain. Also, the building is also equal to the color of the surrounding buildings that use the main colors (Figure 6).

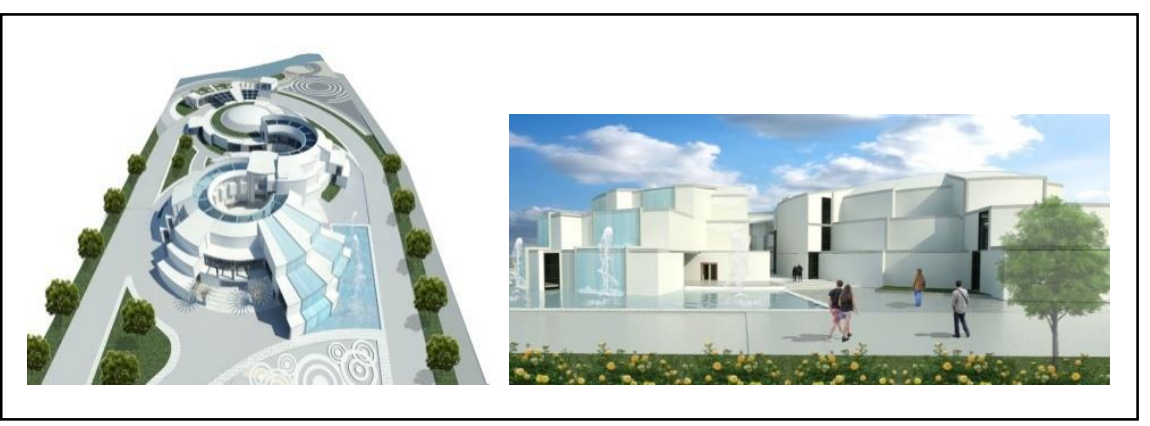

Figure 6. Visual of Building Mass 


\section{Conclusion}

The Paradise North of Sumatra Gallery is planned based on the results of the background and the Needs Issue of the container for art that takes place in the community especially in Medan City. The designed building is a commercial building as a public service facility that accommodates the art space. The unwell contained art spaces in the field of recreation and education, where art shows are for sale. The design location of Paradise North of Sumatra Gallery is located at Patimura street that borders by houses, offices and Babura river. The existence of the river can be a representation of art to the building, where the art of decent space with supporting recreational facilities. Also, the river can be used as one of the attractions for visitors. Because of the potential of riverfront, is usually a unique appeal and not yet widely found in the city of the field so that people will be more enthusiastic about things that have not much been there.

This gallery building consists of 3 functions, namely container exhibition, additional education, and management office. The main exhibition gallery consists of 3 floors. Extra educational buildings and office buildings consist of 1 level. On the construction site, there is a parking lot in the basement. The overall shape of the building forms is round and curved circulation to support the concept of flowing. Vehicle circulation consists of 2 lines that extend 8 meters and 4 meters more circuit for one direction into the basement. The concept of the site also follows the prime idea of metaphorical themes that follow the form of water ripple, which is round. So the shape and pattern of the round about. At the back of the site, the amphitheater is designed on the water. On the amphitheater, side is designed with outdoor café and non-permanent stand. At the back of the education building, there is an outdoor exhibition space without a divider space. So the visitor's flow is started from indoor art showcase - training or education - outdoor exhibit amphitheater - outdoor / Rooftop café.In each part of the outer space, there is a separate concept the visitors who travel from one place to another to feel the experience and quality of different slot. Such as the area piazza, theme or idea in this area more shows the characters by the metaphorical theme of a metaphorical architecture of water ripple which is round-segments. On. In the outer space adjacent to the river, the theme or concept in this area is more cinch, lightweight and natural but leaves no character of the building of art. The notion of outer space is also flowing and not randomly circulated with one another.

It is hoped that the building of Paradise North of Sumatra Gallery will serve as a place to accommodate local artists' artworks and support them with standard gallery facilities to encourage the productivity of local artists to be more developed. The building is expected to become one of the icons or recreation areas that become the city attraction that can be a source of field city revenue. 


\section{Acknowledgment}

This research is part of the requirement to obtain a bachelor's degree in Architecture Department, Universitas Sumatera Utara.

\section{REFERENCES}

[1] R. O. Harrison. The Technical Requirements of Small Museums. Canada: M.RA.IC Technical Paper No, I. 1996.

[2] J. De Chiara and J. Callender. Time-Saver Standards For Building Types: 2nd edition. Singapore: National Printers Ltd. 1987.

[3] S. Jonathan. MetodePenelitianKuantitatifdanKualitatif. Yogyakarta: GrahaIlmu, 2010.

[4] P. Tutt and D. Adler. New Metric Handbook.London: The Architectural Press. 1979. 